\title{
Survival and Spatial Ecology of the Snapping Turtle, Chelydra serpentina, on the Upper Mississippi River
}

\author{
R. Neal Paisley ${ }^{1,2}$, John F. Wetzel ${ }^{1,3}$, John S. Nelson ${ }^{1}$, Cindy Stetzer ${ }^{1,4}$, Mark G. Hamernick ${ }^{1}$, \\ and BENJAMIN P. ANDERSON ${ }^{5}$
}

\author{
${ }^{1}$ Wisconsin Department of Natural Resources, 3550 Mormon Coulee Road, LaCrosse, Wisconsin 54601 USA \\ ${ }^{2}$ Current address: Wisconsin Department of Natural Resources, Sandhill Wildlife Area, P.O. Box 156, Babcock, Wisconsin \\ 54413 USA \\ ${ }^{3}$ Current address: N8020 Amsterdam Prairie Road, Holmen, Wisconsin 54636 USA \\ ${ }^{4}$ Current address: N6162 Jason Street, Onalaska, Wisconsin 54650 USA \\ ${ }^{5}$ Independent Analyst, 4733 Sharon Lane, White Bear Lake, Minnesota 55110 USA
}

Paisley, R. Neal, John F. Wetzel, John S. Nelson, Cindy Stetzer, Mark G. Hamernick, and Benjamin P. Anderson. 2009. Survival and spatial ecology of the Snapping Turtle, Chelydra serpentina, on the Upper Mississippi River. Canadian Field-Naturalist 123(4): 329-337.

\begin{abstract}
We studied the survival and spatial ecology of adult Snapping Turtles (Chelydra serpentina) on Pool 8 of the Upper Mississippi River (UMR) during 1997-2001. We captured 597 Snapping Turtles 745 times (333 adult males; 238 adult females; and 26 juveniles) at two study sites; Goose Island, Wisconsin and Lawrence Lake, Minnesota. From this sample, we radio-marked 104 Snapping Turtles of legal harvest size 128 times. Annual survival ranged from 0.857 to 1.000 and averaged 0.944 with Goose Island and Lawrence Lake estimates pooled. Legal harvest was the most important cause of mortality and accounted for 57\% of documented deaths. Annual home range size using the Poly-Buff (PB) method averaged 11.13 ha and ranged from 2.20 ha to 37.18 ha. Emergent and rooted-floating aquatic vegetation were used disproportionally more than their availability and $72 \%$ of all locations collected during the active period occurred within these habitat types. Overall, radiomarked Snapping Turtles selected hibernacula in the following habitat categories; marshes (38\%), main/side channels $(28 \%)$, backwater sloughs and small ponds (14\%), spring areas (10\%), small tributary streams (7\%), and tertiary channels (3\%). Developing conservative, consistent harvest regulations among the states that border the UMR should be a management priority.
\end{abstract}

Key Words: Snapping Turtle, Chelydra serpentina, habitat use, hibernacula, home range, radio-telemetry, survival, Upper Mississippi River.

The life history strategy of turtles relies heavily upon adult survival to sustain populations due to generally low reproductive success (Brooks et al. 1988, Obbard 1983). Species such as the Snapping Turtle (Chelydra serpentina) and the Spiny Softshell Turtle (Apalone spinifera) are particularly vulnerable to population decline due to interest in harvesting adults of these species for human consumption. These species have traditionally been harvested on the Upper Mississippi River, both commercially and non-commercially (for personal use).

Regulations protecting Snapping Turtles on the Wisconsin and Minnesota boundary waters of the Upper Mississippi River have been liberal and inconsistent between the 2 states. Prior to 1997, Wisconsin boundary waters had a continuous season with no bag limits and a minimum 25.4-cm carapace length size limit. In 1997, a turtle season was established which extended from 15 July to 30 November with a possession limit of 10. A slot limit was also established for Snapping Turtles requiring a $30.5-\mathrm{cm}$ minimum and a $40.6-\mathrm{cm}$ maximum carapace length. Prior to 1998, Minnesota boundary waters also had a continuous season that included a bag limit of 3 Snapping Turtles and no limit for other turtle species. The only size restriction was a 25.4- $\mathrm{cm}$ minimum carapace width for Snapping Turtles. In 1998, Minnesota regulations closed the Snapping Turtle season during May and June. All other turtle harvest regulations remained unchanged. All Snapping Turtles taken incidental to licensed commercial fishing operations could also be possessed.

An important factor that influenced these regulation changes was concern expressed by turtle harvesters that turtle populations were declining, particularly Snapping Turtle and softshell turtle populations on the UMR. They also cited the absence of larger individuals in these populations. A review of the existing literature on turtle ecology yielded limited information to allow proper management of turtle populations on the UMR and elsewhere. Basic information on survival, habitat needs, and spatial dynamics is essential to protecting the species and making informed management decisions.

This study focused on adult females because their survival and reproductive role are critical to sustaining populations. Further, we focused on adult females of legal harvest size to provide estimates of survival for females exposed to commercial and non-commercial 
harvest on the UMR. Our specific objectives were to (1) estimate survival rates and determine causes of mortality, (2) determine habitat use, (3) identify important hibernacula, and (4) estimate home range size.

\section{Study Area}

We conducted research at two study sites (Goose Island: 708 ha; Lawrence Lake: 384 ha) within navigational Pool $8\left(43^{\circ} 43^{\prime} 55^{\prime \prime} \mathrm{N}, 91^{\circ} 14^{\prime} 30^{\prime \prime} \mathrm{W}\right)$ on the UMR (Figure 1). Pool 8 is an impoundment on the Upper Mississippi Wildlife and Fish Refuge and is part of the boundary waters between the rugged driftless areas of Wisconsin and Minnesota. This impoundment is $38.8 \mathrm{~km}$ in length and encompasses 9000 ha of aquatic habitat. The major tributaries include the Black, Root, and LaCrosse rivers (Burkhardt et al. 2001). Numerous smaller tributaries also enter the impoundment from Wisconsin and Minnesota. Public use is high at both study sites. Primary activities are fishing, hunting, trapping, and boating.

The Goose Island study area occurs on the Wisconsin side of the main channel and is characterized by braided channels, floodplain forests, shallow marshes, and small backwater sloughs. Land cover (with primary species in parentheses) consists of $28 \%$ aquatic vegetation including rooted-floating species (American Lotus [Nelumbo lutea], White Waterlily [Nymphaea odorata]), emergent species (River Bulrush [Schoenoplectus fluviatilis], arrowhead spp. [Sagittaria spp.]), and submergent species (pondweed spp. [Potamogeton spp.], Coontail [Ceratophyllum demersum]); $32 \%$ open water; $22 \%$ floodplain forest (Silver Maple [Acer saccharinum], Eastern Cottonwood [Populus deltoides], Green Ash [Fraxinus pennsylvanica]); 17\% wet meadow (Reed Canarygrass [Phalaris arundinacea], Rice Cutgrass [Leersia oryzoides]; and 1\% sand/developed.

Lawrence Lake is a floodplain lake on the Minnesota side of the main channel. Land cover consists of $67 \%$ aquatic vegetation; $17 \%$ open water; $10 \%$ floodplain forest; and $6 \%$ wet meadow. Species composition within habitat types is similar to Goose Island though Lawrence Lake frequently produces an abundance of Wild Rice (Zizania aquatica).

Climate is characterized by relatively long, cold winters and mild summers. Aquatic habitat is typically ice covered from early-December to mid-March. Ice thickness varies considerably from a thin covering on higher flow areas to $50 \mathrm{~cm}$ on backwater areas. Air temperatures range from $-32^{\circ} \mathrm{C}$ to $39^{\circ} \mathrm{C}$ and average $9.3^{\circ} \mathrm{C}$. Annual precipitation averages $91 \mathrm{~cm}$ and snowfall averages $106 \mathrm{~cm}$ each winter.

\section{Methods}

\section{Capture and Handling}

During 1997-2001, we captured Snapping Turtles from late-May to mid-August in shallow marsh habitats. Turtles were captured using baited basket traps, hoop nets, and fyke nets. Traps were typically baited with rough fish heads or sardines and were checked each day. Some turtles were also captured by hand to recover and replace radios that were expected to fail. Physical measurements (carapace length [CL], carapace width, and weight) were collected for all captured Snapping Turtles and sex was determined using the ratio of the pre-cloacal distance to the posterior lobe of the plastron (Mosimann and Bider 1960). Juveniles were defined as turtles with CL $<20 \mathrm{~cm}$ (Mosimann and Bider 1960; White and Murphy 1973; Vogt 1981). Each Snapping Turtle $>18 \mathrm{~cm}$ CL was marked with an aluminum reward band (National Band and Tag Company, Newport, Kentucky) which was attached through a posterior marginal scute (Hammer 1969). Snapping Turtles that were not of legal harvest size were released at the capture site. Those of legal harvest size were transported to the research station to be radio-marked. Mortality-sensitive transmitters (Advanced Telemetry Systems, Isanti, Minnesota) in the 149-150 Mhz range were affixed to the posterior portion of the carapace using fast-setting epoxy. Early in the study, some transmitters were affixed using small stainless-steel bolts and epoxy, but it was determined that epoxy alone provided adequate attachment to the carapace. Radio-marked turtles were held overnight to allow the epoxy to set and released the next morning at the point of capture. Transmitters weighed $30 \mathrm{~g}$ and were programmed with duty cycles to allow 2 years of service. Some males of legal harvest size were also radio-marked due to the difficulty in capturing adequate numbers of legal-sized females. Reward payments were made to individuals who recovered or reported marked Snapping Turtles.

\section{Monitoring}

We located radio-marked turtles with programmable receivers (Advanced Telemetry Systems, Isanti, Minnesota) and 3-element hand-held antennas. Turtle positions were approached slowly using a 4-meter Panther airboat with a 4-cylinder Lycoming engine. The observer was generally able to approach to within $10 \mathrm{~m}$ and the position was determined by circling the turtle until signal direction changed significantly. Habitat data were collected and the position was recorded using a GPS unit (Eagle Electronics, Catoosa, Oklahoma). GPS accuracy was checked on a weekly basis using reference coordinates located at the research station. An attempt was made to obtain locations and monitor survival at least once each week. When contact was lost from the water, aerial searches were conducted using a Cessna 180 Skywagon with dual H-element antennas mounted to the struts.

\section{Survival}

We calculated annual survival on a calendar year basis, using the Kaplan-Meier product limit estimator modified for staggered entry (Pollock et al. 1989). We used a Z-test (Pollock et al. 1989) to compare annual survival by sex and study site. Statistical significance was assessed at $P<0.05$. Turtles surviving $\leq 14$ days were excluded from the survival analyses. 

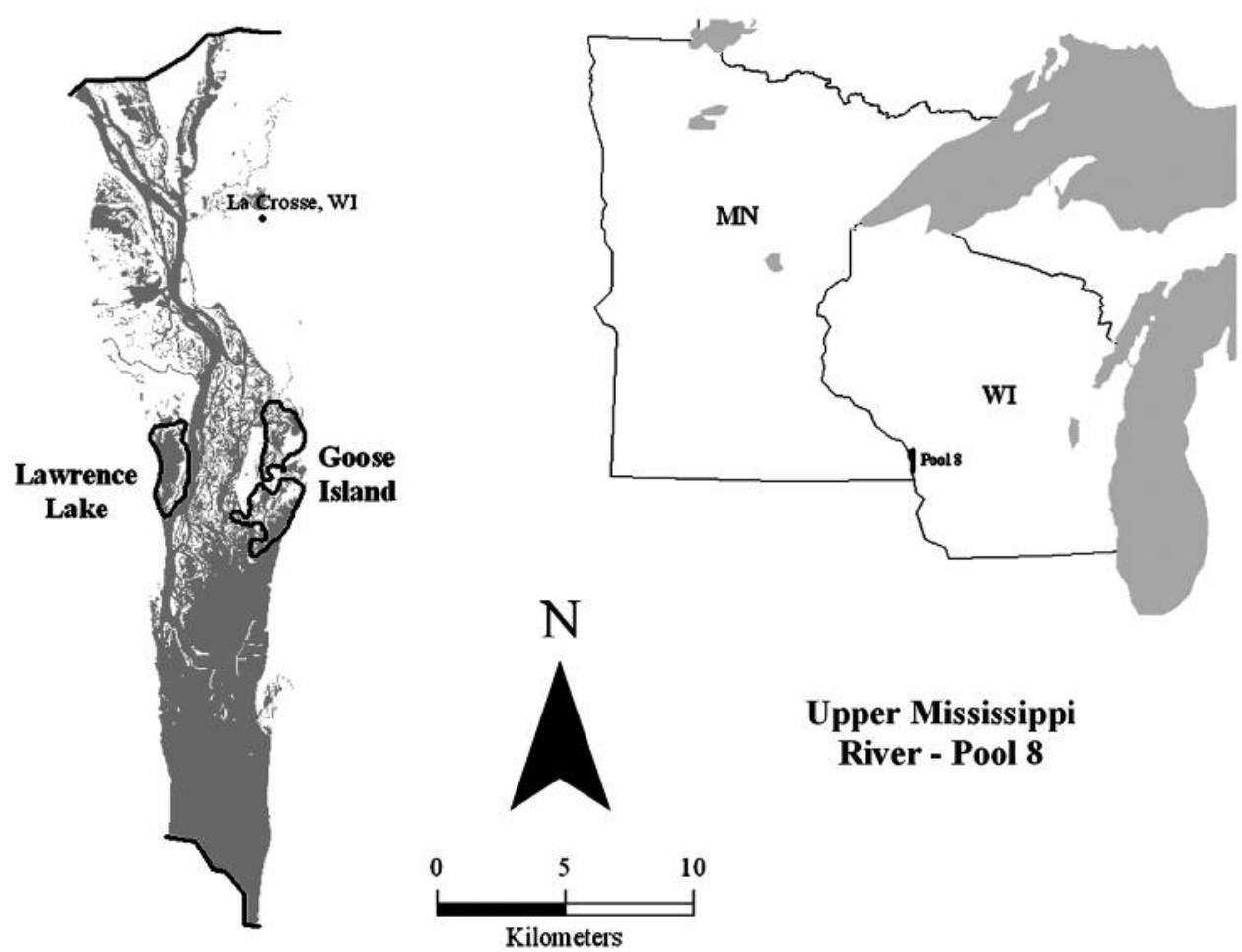

FIGURE 1. Goose Island and Lawrence Lake study areas on Pool 8, Upper Mississippi River, 1997-2001.

\section{Home Range and Habitat Use}

Northing and Easting coordinates collected in the field were integrated into a geographic information system (GIS) to calculate home range sizes for each individual by year, sex, and study site. The criteria used to include individuals for the home range analysis were $(1) \geq 15$ locations were obtained during the active season, (2) monitoring was initiated no later than 10 June to include movements associated with nesting behavior, and (3) monitoring was continuous to the hibernaculum (established as 1 October).

Two methods were used to calculate home range size. The first method, the PB (Poly-Buff) method (Hamernick 2001) is similar to the Cluster Analysis method (Edmonds 1998; Carter et al. 1999). The PB method combines overland movements with areas of aquatic activity by measuring the area within a 20meter path between locations throughout the active season. The Minimum Convex Polygon (MCP) (Mohr 1947, Hooge and Eichenlaub 1997) is a conventional method that has been used extensively in other studies and is included in Table 2 to allow comparison with previous spatial work. Our results are presented using the PB method.

We established seven habitat types to characterize habitats used by Snapping Turtles during the active period: emergent, open water, rooted-floating aquatic, sand/developed, submergent, wet meadow, and woody terrestrial. These habitat types are part of a larger land cover classification system developed in 2000 by the U.S. Geological Survey, Upper Midwest Environmental Sciences Center, LaCrosse, Wisconsin.

\section{Hibernacula}

Hibernacula were generalized into the following floodplain categories:

(1) Main Channel: includes main channel, main channel border, and side channels (secondary channels). Channel types are described in detail by Wilcox (1993).

(2) Tertiary Channel: small floodplain channels $\leq 30 \mathrm{~m}$ wide.

(3) Tributary: small spring-fed streams generally $<10 \mathrm{~m}$ wide that enter the floodplain from adjacent watersheds.

(4) Marsh: shallow backwater areas with little or no flow. These areas are characterized by emergent, root-floating, and submerged vegetation.

(5) Slough/Pond: shallow backwater areas with little or no flow. These are irregularly-shaped water bodies with heavy woody vegetation along shorelines. Sloughs are aquatically connected to other backwater areas and ponds are isolated.

(6) Spring Area: areas with ground water inflow that typically stay at least partially open during winter.

Distances moved from the geometric center of summer use areas to hibernacula were measured using a GIS. Hibernacula area was defined as the area within $100 \mathrm{~m}$ of the hibernaculum. 


\section{Goose Island}

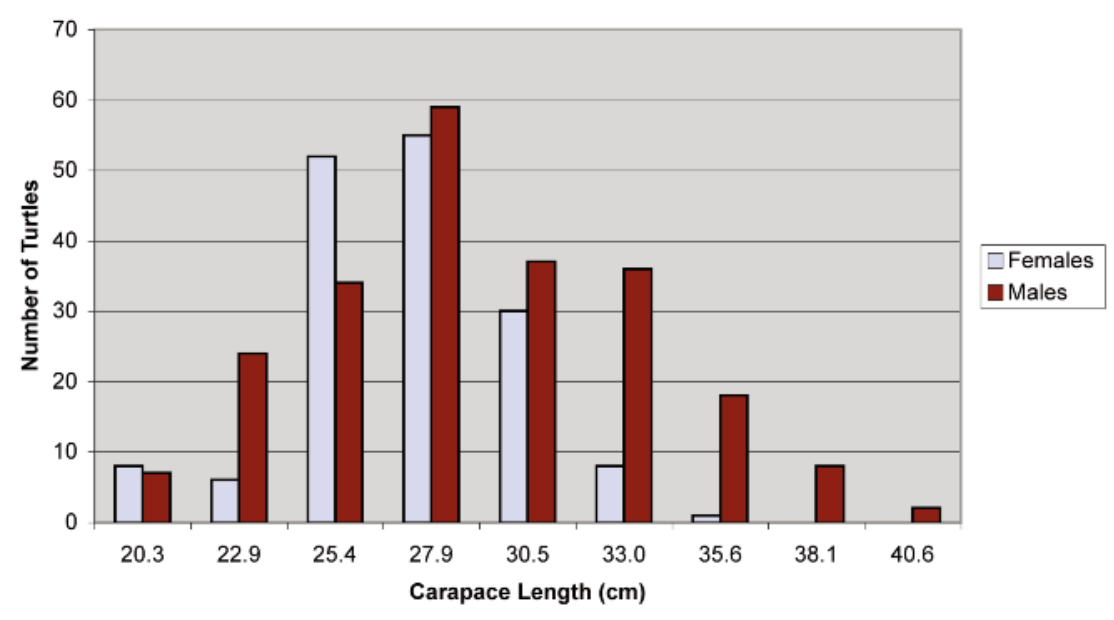

Lawrence Lake

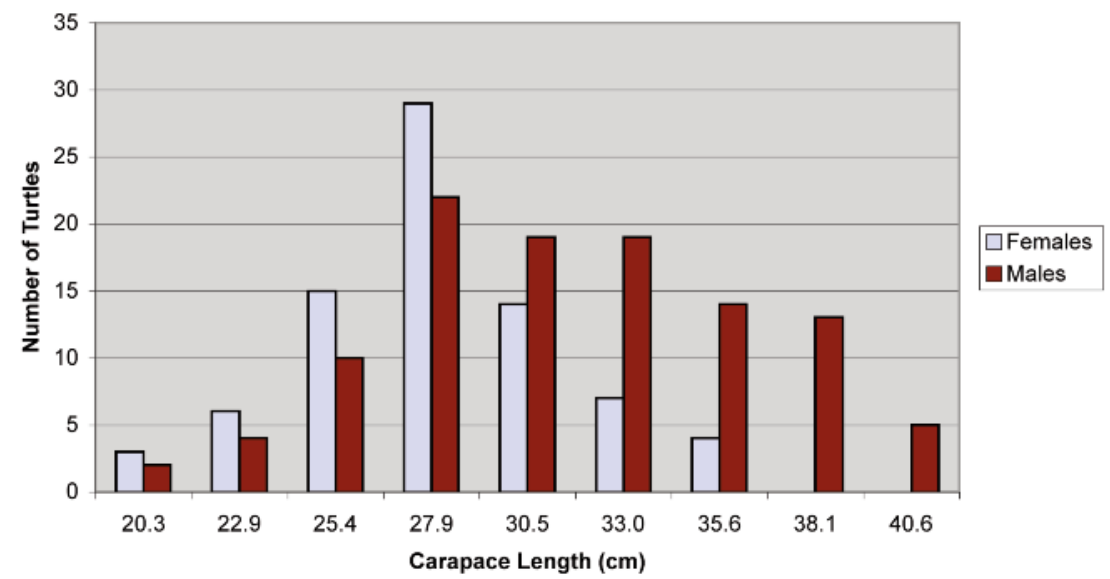

FIGURE 2. Size distribution of initially captured Snapping Turtles at Goose Island and Lawrence Lake study areas on Pool 8, Upper Mississippi River, 1997-2001.

\section{Results}

\section{Capture and Handling}

We captured 597 Snapping Turtles 745 times from May 1997 to August 2001. The capture consisted of 333 adult males, 238 adult females, and 26 juveniles. At the Goose Island study area, 1988 trap nights resulted in the capture of 400 Snapping Turtles (225 adult males [56\%]; 160 adult females [40\%]; 15 juveniles [4\%]). We captured 197 Snapping Turtles (108 adult males [55\%]; 78 adult females [40\%]; 11 juveniles [5\%]) in 871 trap nights at the Lawrence Lake study area. The adjusted overall recapture rate was 0.28 because not all captured juveniles were marked (due to their size). Minimum Snapping Turtle density (based on unique turtles captured) was $0.73 /$ ha at Goose Island and $0.57 /$ ha at Lawrence Lake.

Mean CL of females at Goose Island was $28.2 \mathrm{~cm}$ (range $=20.3-35.6)$ and $29.0 \mathrm{~cm}($ range $=20.3-$ 36.8) for females at Lawrence Lake. Average body mass of adult females at Goose Island and Lawrence Lake was $4.5 \mathrm{~kg}$ (range $=1.4-8.2)$ and $5.1 \mathrm{~kg}($ range $=$ $2.0-10.4$ ), respectively. CL of males averaged $30.0 \mathrm{~cm}$ (range $=20.3-41.4$ ) at Goose Island and $32.3 \mathrm{~cm}$ (range $=20.3-41.9)$ at Lawrence Lake. Adult males averaged $5.6 \mathrm{~kg}$ (range $=1.4-13.6$ ) at Goose Island and $7.2 \mathrm{~kg}$ (range $=1.8-13.8$ ) at Lawrence Lake.

Twenty-four percent of females and $45 \%$ of males were at risk of legal harvest (CL $30.5 \mathrm{~cm}-40.6 \mathrm{~cm}$ ) at 
TABLE 1. Survival rates of radio-marked snapping turtles (sexes pooled) at Goose Island and Lawrence Lake study areas on Pool 8, Upper Mississippi River, 1997-2000.

\begin{tabular}{cccccccc}
\hline \hline & & \multicolumn{3}{c}{ Goose Island } & & \multicolumn{3}{c}{ Lawrence Lake } \\
\cline { 2 - 4 } Year & Survival rate & Standard Error & $\mathrm{n}^{\mathrm{a}}$ & & Survival rate & Standard Error & $\mathrm{n}$ \\
\hline 1997 & 1.000 & 0.000 & 10 & 0.938 & 0.061 & 16 \\
1998 & 0.944 & 0.064 & 19 & 0.857 & 0.065 & 30 \\
1999 & 1.000 & 0.000 & 14 & 0.962 & 0.044 & 27 \\
2000 & 0.909 & 0.097 & 15 & 1.000 & 0.000 & 22 \\
\hline \hline
\end{tabular}

${ }^{a}$ Maximum number of snapping turtles at risk during period of interest.

TABLE 2. Home range sizes (ha) of radio-marked Snapping Turtles at Goose Island and Lawrence Lake study areas on Pool 8, Upper Mississippi River, 1997-2001.

\begin{tabular}{|c|c|c|c|c|c|c|}
\hline \multirow{2}{*}{$\begin{array}{l}\text { Study Area } \\
\text { Year }\end{array}$} & \multicolumn{3}{|c|}{ Female Home Ranges } & \multicolumn{3}{|c|}{ Male Home Ranges } \\
\hline & Poly-Buff & $\mathrm{MCP}$ & $\mathrm{n}^{\mathrm{a}}$ & Poly-Buff & $\mathrm{MCP}$ & $\mathrm{n}$ \\
\hline \multicolumn{7}{|c|}{ Goose Island } \\
\hline 1997 & - & - & 0 & - & - & 0 \\
\hline 1998 & 14.74 & 66.83 & 7 & - & - & 0 \\
\hline 1999 & 10.71 & 26.80 & 9 & 14.18 & 38.23 & 2 \\
\hline 2000 & 13.96 & 36.55 & 2 & - & - & 0 \\
\hline 2001 & 13.27 & 41.62 & 1 & - & - & 0 \\
\hline Overall & 12.67 & 43.36 & 19 & 14.18 & 38.23 & 2 \\
\hline \multicolumn{7}{|c|}{ Lawrence Lake } \\
\hline 1997 & 7.18 & 15.08 & 14 & - & - & 0 \\
\hline 1998 & 13.54 & 30.95 & 12 & 7.17 & 12.69 & 2 \\
\hline 1999 & 11.50 & 36.69 & 15 & 8.60 & 10.20 & 2 \\
\hline 2000 & 11.21 & 29.84 & 8 & - & - & 0 \\
\hline 2001 & 11.65 & 32.24 & 8 & 5.09 & 5.86 & 1 \\
\hline Overall & 10.85 & 28.59 & 57 & 7.33 & 10.33 & 5 \\
\hline Totals & 11.30 & 32.28 & 76 & 9.29 & 18.30 & 7 \\
\hline
\end{tabular}

${ }^{a}$ Number of Snapping Turtle home range values used for analysis.

Goose Island (Figure 2). An important segment of this population occurred just below the minimum legal harvest size (CL $25.4 \mathrm{~cm}-27.9 \mathrm{~cm}$ ). Sixty-seven percent of females and $41 \%$ of males were in this size class. At Lawrence Lake, $96 \%$ of females and $98 \%$ of males were at risk of legal harvest.

\section{Radio-marking}

We radio-marked 104 Snapping Turtles of legal harvest size during the study period (1997-2001). Fortyfive (37 females; 8 males) Snapping Turtles were radio-marked and monitored at Goose Island and 59 (55 females; 4 males) at Lawrence Lake. A total of 128 radios were deployed during the study period.

\section{Survival and Causes of Mortality}

We monitored 89 (78 females; 11 males) unique Snapping Turtles of legal harvest size during 19972000 to estimate survival rates and identify causes of mortality. Annual survival rates did not differ between females and males $(P>0.079)$ at Goose Island and Lawrence Lake. Pooled (sex) annual survival rates ranged from 0.909 to 1.000 at Goose Island and averaged 0.963 (Table 1). Annual survival rates at Law- rence Lake ranged from 0.857 to 1.000 and averaged 0.939. Comparison of survival rates between the study areas showed no significant differences except the 1998 Lawrence Lake estimate (0.857) was significantly lower $(P=0.014)$ than the 1997 Goose Island (1.000) and 1999 Goose Island (1.000) estimates. During 1997-2000, annual survival averaged 0.944 with the Goose Island and Lawrence Lake estimates pooled.

Seven recoveries of radio-marked Snapping Turtles were classified as mortalities during 1997-2000; 5 (4 females; 1 male) at Lawrence Lake and 2 (2 males) at Goose Island. Four (57\%) of these recoveries were related to harvest activities. One was captured in a gill net at Goose Island, incidental to commercial fishing activities. This turtle was kept by the fisherman for personal consumption. A second was captured in a hoop net at Goose Island by a turtle hunter and also kept for personal consumption. Another Snapping Turtle was "hooked" from an important hibernaculum at Lawrence Lake. Hooking is a harvest technique which uses a rod-like tool with a hook at the end and allows turtle harvesters to locate and remove Snapping Turtles from 
hibernacula. The fourth harvest-related recovery was captured through the ice by a fur trapper as he was checking Muskrat, Ondatra zibethicus, traps at Lawrence Lake. The last two recoveries were later released by the harvesters, but were classified as harvest-related mortalities because interviews with the harvesters indicated that these animals would have been killed and used for personal consumption had the turtles not been radio-marked.

We were not able to determine cause for three other mortalities that occurred at Lawrence Lake. In two cases, only skeletal parts and the radio were found. Estimated date of death for both was August. One recovery was from a river bulrush mat and the other was adjacent to an active Beaver run. No evidence was found to suggest cause of death. The last documented mortality was an intact carcass found floating on the surface of the marsh during June. We found no external evidence to suggest cause of death. The carcass was submitted for necropsy, but internal decomposition precluded determining cause of death.

\section{Home Range Size and Habitat Use}

Annual home range sizes were calculated using 1933 locations from 52 (47 females; 5 males) Snapping Turtles during 1997-2001. Annual home range size averaged 11.30 ha for females $(n=76)$ and 9.29 ha for males $(n=7)$ with study sites combined (Table 2$)$. Home range size averaged 12.81 ha at Goose Island $(n=21)$ and 10.57 ha at Lawrence Lake $(n=62)$. Overall, annual home range size averaged 11.13 ha $(n=83)$ and ranged from 2.20 ha to 37.18 ha.

Habitat type was recorded for 2622 locations from 91 (81 females; 10 males) unique Snapping Turtles during 1997-2001. Snapping Turtles used emergent vegetation disproportionately more than the area it represented. Forty-four percent of all locations occurred in emergent vegetation while this habitat type comprised only $12 \%$ of the total land cover. Rooted-floating aquatic vegetation was also used disproportionately more compared with availability. Twenty-eight percent of all locations were in rooted-floating aquatic vegetation while it represented about $20 \%$ of the land cover. All other habitat types had lower use compared with availability: open water (use $=11 \%$ vs. availability $=26 \%$ ), submergent vegetation (use $=7 \%$ vs. availability $=10 \%$ ), wet meadow (use $=8 \%$ vs. availability $=13 \%$ ), and woody terrestrial (use $=2 \%$ vs. availability $=18 \%$ ). Sand and developed areas represented only $1 \%$ the land cover and no locations were obtained within these types.

\section{Use of Hibernacula}

We monitored 97 (85 females; 12 males) unique Snapping Turtles during 1997-2001 which resulted in documenting 160 hibernacula occasions. With study sites pooled, average (mean) date of initial movement to hibernacula areas was 28 September $(n=139)$. Fifty-six percent of radio-marked Snapping Turtles moved to hibernacula areas between 14 September and 7 October, though some turtles began moving to winter sites by August. The average date of hibernacula entry was 26 October $(n=149)$. Fifty-one percent of radio-marked Snapping Turtles exhibited localized behavior between 24 October and 16 November and some individuals were at winter sites by early September. Distances moved from the center of summer use areas to hibernacula $(n=103)$ averaged $621 \mathrm{~m}$ and ranged from $30 \mathrm{~m}$ to $3226 \mathrm{~m}$.

Nearly half $(46 \%)$ of radio-marked Snapping Turtles used marsh locations as wintering sites at Goose Island (Figure 3). Typically, these turtles selected sites under dense vegetative mats composed of river bulrush or reed canary grass in or adjacent to muskrat and beaver runs. Other sites were located in dense, residual vegetation (e.g., Lotus and wild rice stubble) on marsh flats with no apparent structure. Eighteen percent of winter sites were in backwater sloughs and nearly all of these turtles were associated with the shoreline and woody structure (e.g., stumps, fallen trees). Abandoned Beaver bank lodges and undercut root systems of large silver maples were particularly attractive to Snapping Turtles in backwater sloughs. Spring areas comprised $16 \%$ of winter sites. The most important site was a small woodland pond with a silt substrate and dense beds of submerged vegetation (e.g., Coontail). An influx of well water usually kept a small area of the pond ice-free during winter. The remaining winter sites at Goose Island occurred in tertiary channels $(10 \%)$ and small tributary streams (10\%).

At Lawrence Lake, $43 \%$ of documented winter sites were associated with the main channel of the Mississippi River. Nearly all of these turtles (93\%) selected hibernacula in a side channel between Lawrence Lake and the main channel of the Mississippi River. Most of these turtles were associated with undercut shorelines and woody structure. The remaining winter sites at Lawrence Lake occurred in marsh (33\%), backwater sloughs and floodplain ponds (13\%), spring areas $(7 \%)$, and small tributaries (4\%). Microhabitat use was similar to what we observed at Goose Island.

Overall (study sites pooled), winter sites $(n=160)$ occurred in marsh $(38 \%)$, main/side channel $(28 \%)$, backwater sloughs and small ponds (14\%), spring areas $(10 \%)$, small tributary streams $(7 \%)$, and tertiary channels $(3 \%)$. Water depth at hibernacula averaged $0.4 \mathrm{~m}$ and ranged from 0.1 to $1.8 \mathrm{~m}$. Forty-one percent of wintering Snapping Turtles were within 1 meter of a shoreline. Woody structure was observed at $37 \%$ of winter sites. Sixteen percent of hibernacula were associated with old Beaver bank lodges, muskrat houses, and active Beaver/Muskrat runs. Radio-marked Snapping Turtles began emerging from hibernacula $(n=69)$ by late March and most (68\%) emerged by 17 April. However, some Snapping Turtles remained localized at hibernacula until early May. Movement from hibernacula areas to summer use areas $(n=72)$ began in late 
March. Though a few individuals did not leave hibernacula areas until early June, most movement (82\%) to summer use areas occurred by 6 May.

\section{Discussion}

Annual survival rates of adult Snapping Turtles averaged 0.944 at Goose Island and Lawrence Lake with estimates pooled. Congdon et al. (1994) reported annual survivorship of adult females ranged from 0.880 to 0.970 for a Michigan population. They also found population stability was most sensitive to changes in adult and juvenile survival and less sensitive to changes in age at sexual maturity, nest survival, or fecundity. Galbraith and Brooks (1987) estimated adult female survivorship at 0.966 for an Ontario population over a 13year period. This was followed by a two-year period when annual survival of adult females was estimated to be 0.800 and 0.550 . The primary cause of the increase in mortality was predation by North American River Otters (Lontra canadensis) during hibernation (Brooks et al. 1991).

We determined that legal harvest was the most important cause of mortality at Goose Island and Lawrence Lake during 1997-2000. Legal harvest accounted for $57 \%$ of the known mortalities that occurred. During our study, turtle harvesters reported recoveries of radio-marked and banded Snapping Turtles to obtain a reward payment. This provided an opportunity to conduct informal interviews with the turtle harvesters and gain some perspective on trends in turtle harvest and populations on Pool 8. From recoveries of radiomarked and banded Snapping Turtles, we documented that four turtle harvesters were actively trapping Snapping Turtles with hoop nets at Goose Island and one commercial fisherman was operating gill nets at Goose Island. At Lawrence Lake, we determined that two harvesters were actively taking Snapping Turtles. One was operating hoop nets and one was hooking Snapping Turtles from a tributary that entered Lawrence Lake. Interviews with these experienced harvesters indicated that Snapping Turtle populations have declined considerably during the past 20-30 years and larger individuals $(>40.0 \mathrm{~cm} \mathrm{CL})$ are rare. These harvesters also indicated that current harvest levels are low and most harvesters only keep a few legalsized Snapping Turtles for personal consumption.

Other sources of mortality that were not documented by our study, but are known to affect northern Snapping Turtle populations include vehicle-caused mortality, predation, and bacterial infection. Vehiclecaused mortality has been well documented (Vogt 1981, Oldfield and Moriarty 1994; Galbraith 2008) and was commonly observed during the nesting season (our study) as females attempted to nest along road shoulders or cross the heavily traveled state highways adjacent to both Goose Island and Lawrence Lake. North American River Otters have been documented to cause significant mortality to local Snapping Turtle
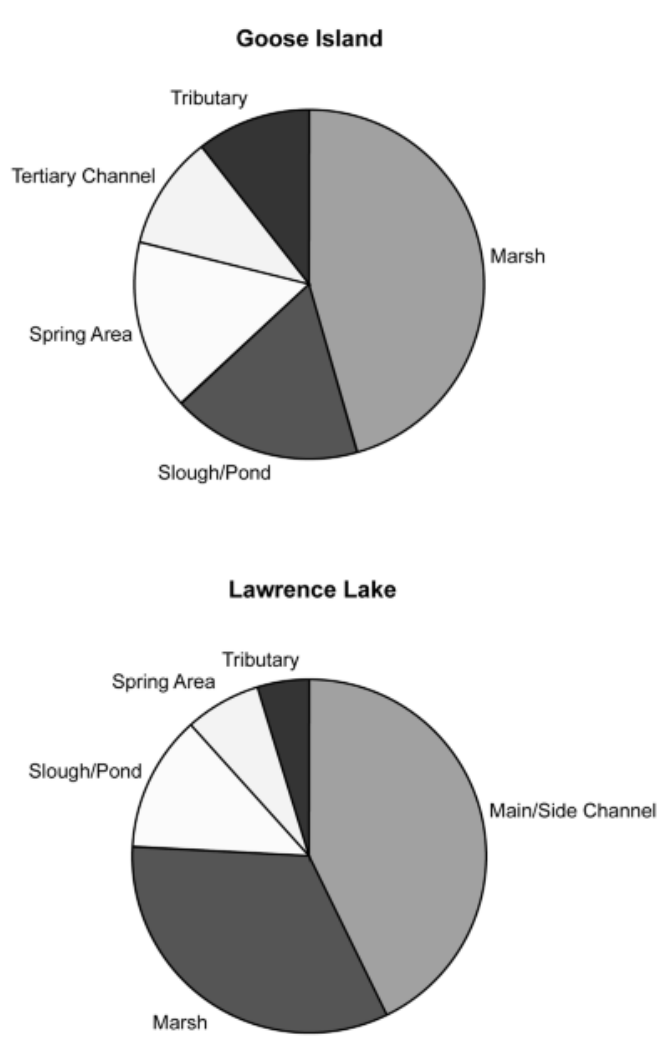

FIGURE 3. Distribution of overwintering radio-marked Snapping Turtles by habitat category at Goose Island and Lawrence Lake study areas on Pool 8, Upper Mississippi River, 1997-2001.

populations at hibernacula during winter. Brooks et al. (1991) recovered 34 adult Snapping Turtle carcasses at their Ontario study area during two winters and determined that most were killed by otters at hibernacula. Park (1971) also reported otters exploiting wintering Snapping Turtles. During one winter, on a three-mile stretch of stream in northern Wisconsin, 27 Snapping Turtle carcasses were observed on the ice following predation by otters. Brooks et al. (1991) noted a few Snapping Turtles died shortly after emerging from hibernation from bacterial infection (septicemia).

Our estimates of home range size were considerably larger than those reported by previous work. Obbard and Brooks (1981) reported home range size averaged 3.44 ha for 10 radio-marked Snapping Turtles at Algonquin Park, Ontario (using the MCP method). Galbraith et al. (1987) also studied home range size at Algonquin Park during a later study period and determined home range size averaged 1.48 ha using the MCP method $(n=7)$. Murphy and Sharber (1973) found home range 
sizes averaged 0.65 ha for three radio-marked Snapping Turtles at a Tennessee River study site. By comparison, our MCP home ranges averaged 31.10 ha $(n=83)$ with study sites and sexes combined and the PB mean was 11.13 ha. One plausible explanation for the large home range sizes we observed may be that the vast expanse of aquatic habitat available to Snapping Turtles on the UMR allowed for a greater range of movement with relatively low energetic cost.

The PB method (Hamernick 2001) that we used may be more relevant for estimating home range size for aquatic chelonians because it excludes potentially large areas of terrestrial habitat that would be included in calculating home range size with a method such as the MCP. Similar to the findings of Hamernick (2001), we determined that the PB home range estimates were much more conservative than estimates using the MCP method. Overall, our PB estimates were approximately $1 / 3$ the size of the home range estimates using the MCP method.

We observed snapping turtles overwintering singly and communally at Goose Island and Lawrence Lake. Snapping Turtles tended to overwinter communally at backwater sloughs/ponds (primarily in abandoned Beaver bank lodges), spring areas, and tributaries compared to other hibernacula types. An overwintering site of particular significance was the side channel between Lawrence Lake and the main channel of the Mississippi River. Nearly half (40\%) of the documented winter sites at Lawrence Lake occurred at this hibernaculum. The side channel was approximately $1600 \mathrm{~m}$ long and $40 \mathrm{~m}$ wide with an average depth of $1.0 \mathrm{~m}$. Use of this hibernaculum required Snapping Turtles to cross an approximately $70 \mathrm{~m}$ strip of wooded upland from Lawrence Lake. The west shoreline was particularly attractive to wintering Snapping Turtles due to heavy woody structure. Seventy-six percent of the winter sites within this side channel were associated with woody structure. Nearly all of the winter sites not associated with woody structure occurred beneath undercut banks. Snapping Turtles used deeper microhabitat $(0.6 \mathrm{~m})$ within this hibernaculum compared to the overall mean depth $(0.4 \mathrm{~m})$ that Snapping Turtles selected at other sites.

Data from the Long Term River Monitoring Program (LTRMP) (Shawn Giblin, unpublished data) indicated that dissolved oxygen levels in the side channel were substantially higher $($ mean $=10.95 \mathrm{mg} / \mathrm{L}$ ) than sites sampled at Lawrence Lake marsh locations $($ mean $=4.81 \mathrm{mg} / \mathrm{L})$ during winter (1993-2007). LTRMP sampling also documented that water velocity was higher in the side channel (mean $=0.105 \mathrm{~m} / \mathrm{s}$ ) compared with Lawrence Lake marsh sites (mean = $0.0018 \mathrm{~m} / \mathrm{s}$ ) during winter. These data provide a possible explanation why such a high proportion of the Lawrence Lake population moved to this site to hibernate.

\section{Management Implications}

We determined that legal harvest was the most important cause of mortality of adult Snapping Turtles at the Goose Island and Lawrence Lake study areas. While we do not know if recruitment was compensating for this level of mortality, existing literature suggests that Snapping Turtle reproductive success is low and that even low levels of adult mortality may result in population decline (Obbard 1983; Congdon et al. 1987; Congdon et al. 1994; Cunnington and Brooks 1996). From a broader perspective, interviews with turtle trappers and discussions with commercial fishermen indicate that Snapping Turtle populations have declined substantially over the past 20-30 years on Pool 8 of the UMR.

Developing conservative, consistent harvest regulations among the states that border the Upper Mississippi River should be a management priority. The sexual disparity that we observed at both study sites (56\% adult males: $40 \%$ adult females) warrants a harvest strategy that would at least discourage taking adult females. This could easily be done with a simple drawing in harvest regulation pamphlets that would show cloacal position relative to posterior edge of the carapace to distinguish males from females.

Current turtle regulations in Minnesota and Wisconsin provide protection to Snapping Turtles during the nesting season, but do not adequately protect Snapping Turtles during hibernation when they aggregate (Meeks and Ultsch 1990; Brown and Brooks 1994; Ultsch 2006) and are particularly vulnerable to exploitation. Even with conservative bag limits, these are sites where harvesters can consistently take substantial numbers of adult Snapping Turtles. Using the average dates of hibernacula entry and emergence from this study, protection would effectively be provided if the season were closed from the beginning of October through April. Further, these important overwintering sites need to be considered when habitat projects are being planned on Pool 8 and should be used to model other wintering sites on the UMR.

\section{Acknowledgments}

We thank research assistants Jenny Fiedler, Leanne Ganz, Jay Puente, Mark Shepherdson, and Scott Zeimetz for their hard work and dedication to this effort. This project would not have been possible without the generous funding provided by the Paul E. Stry Foundation and the U. S. Geological Survey. We thank Bob Hay, Jerry Bartelt, and Robert Rolley for assisting study development and supporting the project. Gordon Ultsch facilitated funding efforts. Andy Bartels and Eric Kramer assisted with capture of Snapping Turtles. Bob Hay and Gordon Ultsch reviewed an early draft of the manuscript. We thank Roger Beck and Donald Bramwell of Beck's Fish Market for generously providing our study with trap bait. Jason Roweder con- 
ducted preliminary analyses of the spatial data. Jeff Boyne provided weather summary data.

\section{Literature Cited}

Brooks, R. J., D. A. Galbraith, E. G. Nancekivell, and C. A. Bishop. 1988. Developing management guidelines for snapping turtles. Pages 174-179 in Proceedings of management of amphibians, reptiles, and small mammals in North America.

Brooks, R. J., G. P. Brown, and D. A. Galbraith. 1991. Effects of a sudden increase in natural mortality of adults on a population of common snapping turtle (Chelydra serpentina). Canadian Journal of Zoology 69: 1314-1320.

Brown, G. P., and R. J. Brooks. 1994. Characteristics of and fidelity to hibernacula in a northern population of Snapping Turtles, Chelydra serpentina. Copeia 1994: 222-226.

Burkhardt, R. W., S. DeLain, E. Kramer, A. Bartels, M. C. Bowler, E. Ratcliff, D. P. Herzog, K. S. Irons, and T. M. O'Hara. 2001. 1999 Annual Status Report: A summary of fish data in six reaches of the Upper Mississippi River System. U.S. Geological Survey, Upper Midwest Environmental Sciences Center, LaCrosse, Wisconsin, July 2001. LTRMP 2001-P002. 14 pages. + Chapters 1-6

Carter, S. L., C. A. Haas, and J. C. Mitchell. 1999. Home range and habitat selection of bog turtles in southwestern Virginia. Journal of Wildlife Management 63: 853-860.

Congdon, J. D., G. L. Breitenback, R. C. van Loben Sels, and D. W. Tinkle. 1987. Reproductive and nesting ecology of Snapping Turtles (Chelydra serpentina) in southeastern Michigan. Herpetologica 43: 39-54.

Congdon, J. D., A. E. Dunham, and R. C. van Loben Sels. 1994. Demographics of common snapping turtles (Chelydra serpentina): Implications for conservation and management of long-lived organisms. American Zoologist 34: 397-408.

Cunnington, D. C., and R. J. Brooks. 1996. Bet-hedging theory and eigenelasticity: a comparison of life histories of loggerhead sea turtles (Caretta caretta) and snapping turtles (Chelydra serpentina). Canadian Journal of Zoology 74: 291-296.

Edmonds, J. H. 1998. Population ecology of the stinkpot turtle (Sternotherus odoratus) in the Georgian Bay, Ontario. MS thesis, University of Guelph, Guelph, Ontario.

Galbraith, D. A. 2008. Population biology and population genetics. Pages 168-180 in Biology of the Snapping Turtle (Chelydra serpentina). Edited by A. C. Steyermark, M. S. Finkler, and R. J. Brooks. The Johns Hopkins University Press, Baltimore, Maryland, USA.

Galbraith, D. A., and R. J. Brooks. 1987. Survivorship of adult females in a northern population of common snapping turtles, Chelydra serpentina. Canadian Journal of Zoology 65: 1581-1586.

Galbraith, D. A., M. W. Chandler, and R. J. Brooks. 1987. The fine structure of home ranges of male Chelydra serpentina: are snapping turtles territorial? Canadian Journal of Zoology 65: 2623-2629.
Hamernick, M. G. 2001. Home ranges and habitat selection of Blanding's turtles (Emydoidea blandingii) at the Weaver Dunes, Minnesota. M.S. thesis. Saint Mary's University, University of Minnesota.

Hammer, D. A. 1969. Parameters of a marsh Snapping Turtle population, LaCreek Refuge, South Dakota. Journal of Wildlife Management 33: 995-1005.

Hooge, P. N., and B. Eichenlaub. 1997. Animal movement extension to arcview version 1.1. Alaska Biological Science Center, U. S. Geological Survey, Anchorage, Alaska, USA.

Meeks, R. L., and G. R. Ultsch. 1990. Overwintering behavior of snapping turtles. Copeia 1990: 880-884.

Mohr, C. O. 1947. Table of equivalent populations of North American small mammals. American Midland Naturalist 37: 223-249.

Mosimann, J. E., and J. R. Bider. 1960. Variation, sexual dimorphism, and maturity in a Quebec population of the common snapping turtle, Chelydra serpentina. Canadian Journal of Zoology 38: 19-38.

Murphy, G. G., and J. F. Sharber, Jr. 1973. Preliminary analysis of activity of the common snapping turtle, Chelydra serpentina, as determined by biotelemetry. Journal of Tennessee Academy of Science 48: 56.

Obbard, M. E. 1983. Population ecology of the common snapping turtle, Chelydra serpentina, in north-central Ontario. Ph.D. dissertation, University of Guelph, Guelph, Ontario.

Obbard, M. E., and R. J. Brooks. 1981. A radio-telemetry and mark-recapture study of activity in the common snapping turtle, Chelydra serpentina. Copeia 3:630-637.

Oldfield, B., and J. J. Moriarty. 1994. Amphibians and reptiles native to Minnesota. University of Minnesota Press, Minneapolis, Minneapolis. 237 pages.

Park, E. 1971. The world of the otter. J. B. Lippincott Company. New York, New York 159 pages.

Pollock, K. H., S. R. Winterstein, C. M. Bunck, and P. D. Curtis. 1989. Survival analysis in telemetry studies: the staggered entry design. Journal of Wildlife Management 53: 7-15.

Ultsch, G. R. 2006. The ecology of overwintering among turtles: where turtles overwinter and its consequences. Biological Review 81: 339-367.

Vogt, R. C. 1981. Natural history of amphibians and reptiles of Wisconsin. Milwaukee Public Museum, Milwaukee, Wisconsin 205 pages.

White, J. B., and G. G. Murphy. 1973. The reproductive cycle and sexual dimorphism of the common Snapping Turtle, Chelydra serpentina serpentina. Herpetologica 29: 240-246.

Wilcox, D. B. 1993. An aquatic habitat classification system for the Upper Mississippi System. U. S. Fish and Wildlife Service, Environmental Management Technical Center, Onalaska, Wisconsin. EMTC 93-T003. 9 pages + Appendix A.

Received 5 August 2009

Accepted 18 April 2010 